\title{
Papers
}

\section{Limiting liability}

Received (in revised form): 31st July, 2006

\begin{abstract}
Sarah Wilson LLB, ACIArb
is an associate solicitor within Watson Burton LLP's Construction \& Engineering Department, one of the largest specialist construction legal departments outside of London. Sarah's clients vary from developers and main contractors through to design professionals and sub-contractors. She specialises in large-scale, high-value engineering and construction disputes and has wide-reaching experience of various dispute resolution forums such as the Technology and Construction Court, arbitration, adjudication and mediation. She is an associate of the Chartered Institute of Arbitrators and is the Treasurer of the Northumbria branch.
\end{abstract}

Correspondence: Sarah Wilson, Watson Burton LLP, 1 St James' Gate, Newcastle upon Tyne, NE99 1YQ, UK, Tel: +44 (0)191 2444336 Fax: + 44 (0)191 244 4500, E-mail: sarah.wilson@watsonburton.com

\section{Abstract}

This paper gives an outline of the new regime of Limited Liability Partnerships (LLP) in the context of the construction industry, to demonstrate factors to be taken into account when deciding which business vehicle is best suited to them, whether a partnership, an LLP or a limited company. It focuses on introducing LLPs and the liability that comes with them as well as the consequences to those contracting with them.

Journal of Building Appraisal (2006) 2, 183-187. doi:10.1057/palgrave.jba.2950037

\section{Keywords:}

private limited company, Limited Liability Partnership, members, disclosure, regulation

\section{LIMITED LIABILITY PARTNERSHIPS}

Engineers, architects, quantity surveyors - indeed most professionals involved in the construction industry are involved through a partnership. There is, however, a recently introduced structure for businesses, the Limited Liability Partnership (LLP), which combines the limited liability element of a private limited company with the flexibility of a partnership and any traditional partnership should, at the very least, consider whether a change to LLP status is desirable.

LLPs are governed by the Limited Liability Partnership Act 2000 (LLP Act) and were introduced in April 2001. But overall, the LLP structure bears more resemblance to that of a private limited company than partnership. The similarities with a partnership may be regarded as the exception rather than the rule.

\section{STRUCTURE}

An LLP is a body corporate, in the same way as a private limited company, and as such, has separate legal personality to the partners (or members as they are called in the LLP Act). In its own capacity and name it can:

- hold property;

- employ people;

- enter into contractual obligations;

- incur debts;

- bring and defend proceedings. 


\section{CREATION}

An LLP is created in a similar way to a private limited company: registration of the business with the Registrar of Companies and the issue of a Certificate of Incorporation. In contrast, there is no registration process for partnerships on formation and no prerequisite for a written partnership agreement. The existence of a partnership is a question of fact.

In contrast to a company, however, the LLP Act gives an unlimited capacity to act so there is no restriction and no need to consider the objects and powers of the LLP, nor a Memorandum of Association. This means that third parties contracting with an LLP need not have any concerns about restrictions on the activities of the business.

\section{LIMITED LIABILITY}

As the name suggests, an LLP limits the liability of its partners. The separate corporate identity of the LLP means that any recourse will be against the LLP and not the partners personally. This is obviously a huge advantage over a traditional partnership where the individual partners are personally responsible for the debts and liabilities of the partnership.

The liability of members of an LLP is analogous to that of the shareholders and officers (ie directors) of a private company limited by shares or guarantee whereby shareholders are liable to pay whatever is left unpaid on their shares, or the amount that they have guaranteed, respectively, in the event of insolvency. Beyond this amount, they have no further liability.

The exception to this is negligent misstatement where the member involved may be personally liable along with the LLP. This is particularly relevant for LLPs in the construction industry engaged in the provision of advice.

The limit of liability is the factor that will be of greatest interest to those employing a partnership. Bear in mind that professionals in the majority of cases do have professional indemnity (insurance) cover in respect of advice and design. Therefore, at first glance, limiting liability of individual members may not seem to have any relevance to those contracting with an LLP. Insurance, however, does not cover all scenarios (eg debts, fraud) and in certain situations insurers can avoid the policy (eg for failure to notify promptly). In these situations, the extent of members' liability is of great relevance.

A traditional partnership arrangement provides no protection to the partners and each is personally liable for debts of the partnership. There is no limit to this liability and as such, their personal assets (eg property, shares, bank accounts) are potentially at risk to pay any award, debt or claim against them. To an employer it therefore seems to be an advantage to employ a traditional partnership rather than an LLP, because the likelihood is that the individual partners will have substantial personal assets. Care should be taken, however, in placing great reliance upon this, particularly in respect of large projects that tend to generate large claims. In these circumstances, the assets of individual partners may be a mere 'drop in the ocean'.

As a partner, it must be preferable to have the benefit of limited liability status than not to have it and this is probably the main reason why partnerships make the move to become an LLP.

\section{DISCLOSURE AND FINANCIAL INFORMATION}

An LLP has a disclosure regime similar to that of a company and is obliged to:

- file accounts;

- file an annual return; 
- notify the Registrar of Companies of any changes to membership;

- notify the Registrar of Companies of any changes in the designated members (see below);

- notify the Registrar of Companies of any change to the registered office.

The privacy afforded to a partnership is not available to an LLP and this may prove undesirable to some businesses. In contrast, a partnership is not obliged to make information, such as their annual accounts, available to the public. The disclosure requirements for a partnership are not nearly as complex or wide-ranging as those of a company or LLP. A business intending to contract with a partnership, however, would want some of the same details to be disclosed.

Such information, however, will be a real bonus and of great interest to a party considering contracting with the LLP and particularly an employer. This applies both at contract stage and prior to commencing any proceedings and it should become common practice to carry out the same searches in relation to LLP's as to limited companies to establish status and credit worthiness, etc.

\section{REGULATION OF THE BUSINESS}

Here, the LLP shows greater similarity with a partnership than a private limited company.

An LLP is advised to have a Members Agreement to supplement the framework laid by the LLP Act in the same way as a Partnership Agreement is created to supplement provisions set out in the Partnership Act 1890. Both Acts provide a framework but allow the details to be fleshed out and tailored to suit the individual business. Both provide a set of default rules, which it is advisable to vary, applicable where no agreement has been made to the contrary. For example, both the Partnership Act and the Regulations provide that partners/members are entitled to share equally in the profits in the firm (s.24(1) Partnership Act and Regulation (7(1)) which may not reflect the intentions of the business. This provides a greater degree of flexibility attractive to businesses so that they can manage the business to its greatest potential. All but the simplest of LLPs will require variation from the default rules in the LLP Act.

In contrast, a private limited company is closely regulated by the Companies Act 1985 and other legislation. The scope for parties to choose how to regulate and run their business is much more limited.

It should not be forgotten, however, that the management of an LLP is also affected by not only a large amount of the Companies Act 1985, but also by the Director's Disqualification Act 1986 and the Insolvency Act 1986.

\section{MEMBERS}

An LLP has no directors or shareholders but instead has members who must be registered with the Registrar of Companies.

Like a partnership, each LLP must have at least two members. If the membership falls to one for a period of six months, the limited liability is lost and the remaining member will become liable, alongside the LLP, for debts and liabilities of the firm. This is a good reason why checks and searches should be carried out when in a trading relationship with an LLP throughout the relationship. 
In contrast, the membership of a private limited company may fall to, or be, one person indefinitely without loss of limited liability status.

\section{RELATIONSHIP BETWEEN THE MEMBERS AND THIRD PARTIES}

Every member of an LLP is an agent of the LLP. In a similar way to the Partnership Act 1890, however, the LLP Act provides that if a member is acting without actual authority, and the person he is dealing with either knows that he does not have the authority, or does not know or believe him to be a member, the LLP will not be bound by his acts.

When a person ceases to be a member, they can still operate as an agent of the LLP until the third party is notified or notice is sent to the Registrar of Companies. It is therefore crucial that the LLP ensures the information at the Registrar of Companies is kept up to date.

\section{TAX}

Like a partnership, an LLP is not a taxable person, and as such, the members of an LLP are taxed individually therefore offering less scope for tax planning in relation to the income profits. These are taxed as income of the partners whether actually paid to them or retained in the business.

In contrast, however, a company's tax will depend on how the company uses its profits; different uses attract different rates of tax. For example, paying a director's fee is the most tax-efficient use of profits.

Generally, now, only small differences exist between the rate of tax applying to individuals and companies. Where profits are sufficiently large that there is a real possibility of tax planning, the greater flexibility provided by the system of company taxation may be advantageous.

\section{CONCLUSION}

The choice involving an LLP, a partnership and a private limited company is likely to arise in two circumstances: the start-up of a business, or the conversion of a partnership.

In considering such a choice, all three entities have their distinct advantages and disadvantages, although the importance that each of these plays is determined by the business itself.

In converting a partnership to an LLP, the cost of drafting the Members Agreement, the management of disclosure, novation of key contracts and the transfer to the LLP of assets should be borne in mind.

An LLP will provide a flexible decision-making regime allowing member to tailor the structure and workings of the business to fit their needs. The members are protected by limited liability. This is attractive for members although may not be for those contracting with them. As mentioned above, the amount in question, however, must be borne in mind. The tax issue may be seen to some as an advantage and to others as not so. The public disclosure and potential personal guarantees that may be required to borrow money tend to be a disadvantage. In contrast, this may be seen as attractive to companies looking to contract with them. Also, an LLP is subject to much of the legislation that governs the behaviour of companies.

The introduction of LLPs adds a new dimension to the way in which businesses can be run and, as shown above, this is relevant not only to the business itself but also to third parties involved with the business. It is always important to know who and what you are dealing with. 
Having reviewed the importance of limited liability status within partnerships, the same issue is now considered with regard to directors, shareholders and other third parties in relation to limited companies.

\section{Disclaimer}

This paper is designed to alert professionals. It cannot be, nor is it designed to replace the need for advice on specific issues or circumstance. 